\title{
The effect of carbohydrate mouth rinse on intermittent sprint performance in soccer players*
}

\section{Ağızda karbonhidrat çalkalamanın futbolcularda aralıklı sprint performansı üzerine etkileri*}

Raci Karayıgıt, Hakan Karabıyık, Burak C.Yaslı, Mitat Koz, Gulfem Ersoz

Department of Coaching Education, Faculty of Sport Sciences, Ankara University, Ankara, Turkey

Geliş Tarihi: $30.11 .2017 \quad$ Kabul Tarihi: 05.12.2017 Doi: 10.21601/ortadogutipdergisi.359888

*22. European College of Sport Science (ECSS, 2017, Almanya) Kongresi’nde sözel bildiri olarak sunulmuştur.

\begin{abstract}
Aim: Carbohydrate $(\mathrm{CHO})$ mouth rinsing in the oral cavity has been shown to increase especially endurance exercise performance. Mechanisms responsible for this ergogenic effect may be related to receptors in oral cavity that detect $\mathrm{CHO}$, in turn, increase neural drive to the motor unite. The aim of this study was to examine the effects of $\mathrm{CHO}$ mouth rinsing on intermittent sprint performance in soccer players.

Material and Method: With randomised, double-blind, crossover, counterbalanced research design, fifteen amateur male soccer players (Mean $\pm \mathrm{SD}$ age:20.00 \pm 2.44 years, height:177.66 $\pm 4.80 \mathrm{~cm}$, body mass:75.02 $\pm 6.42 \mathrm{~kg}$ ) completed 3 sessions consisting of $12 \times 4$ seconds intermittent sprint tests with administering 10 -second mouth rinse protocols before each sprint; a-) \%6.4 carbohydrate solution (CHO) b-) water as a placebo (PLA) and 3-) no rinse as a control $(\mathrm{CON})$. At rest, immediately after test and in active and passive recevory periods, blood glucose (BG), blood lactate (BL), heart rate (HR) and rating of perceived exertion (RPE) were assessed.

Results: Compared with the CON condition, $\mathrm{CHO}$ and PLA increased significantly peak and mean power output $(\mathrm{P}<0.05)$, but there was no difference between $\mathrm{CHO}$ and PLA condition. BL and BG values were not statistically different between condition ( $\mathrm{P}>0.05)$ but HR were significantly different in CON than CHO and PLA. Morover, RPE was significantly different in CON than PLA but not than CHO.
\end{abstract}

Conclusion: $\mathrm{CHO}$ mouth rinsing does not improve peak and mean power when compared to PLA, but as a nocebo effect, $\mathrm{CHO}$ and PLA improve peak and mean power output with regard to CON.

Keywords: Football, cycling, oral receptors, mouth wash, ergogenic aid 


\section{Öz}

Amaç: Ağız boşluğunda karbonhidratın ( $\mathrm{CHO}$ ) çalkalanması özellikle dayanıklılık performansında artışlar yaratmaktadır. Bu ergojenik etkiden sorumlu mekanizmalar CHO'yu algılayan ağız boşluğundaki reseptörlerle ilişkili olabilir, dolayısıyla motor ünite sinir uyarımını artırabilir. Bu çalışmanın amacı CHO ağızda çalkalamanın futbolcularda aralıklı sprint performansı üzerine etkilerini araştırmaktır.

Gereç ve Yöntem: Randomize, çift kör, çapraz döngülü, karşılıklı dengeli araştırma dizaynı ile, 15 amatör futbolcu

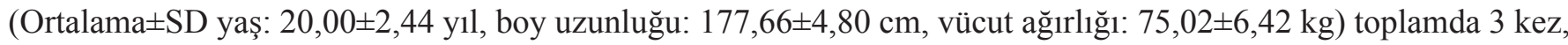
12x4 saniyelik aralıklı sprintlerden oluşan protokolü her sprintten önce [a-) \%6,4 karbonhidrat solüsyonu (CHO) b-) plasebo olarak su (PLA) ve c-) kontrol olarak çalkalama yapmadan (CON)] 10 saniye ağızda çalkalayarak tamamladı. Dinlenimde, testten hemen sonra, aktif ve pasif toparlanmada kan glikozu (GL), kan laktatı (BL), kalp atımı (HR) ve algilanan zorluk derecesi (RPE) kayıt edildi.

Bulgular: CON ile kıyaslandığında, CHO ve PLA zirve ve ortalama güç verilerinde anlamlı artışlar vardı ancak CHO ve PLA arasında herhangi bir fark bulunamadı. BL ve BG değerlerinde koşullar arasında fark bulunamazken ( $\mathrm{P}>0.05)$ HR değerleri CHO ve PLA'ya göre CON koşulunda anlamlı derecede farklıydı. Ayrıca, RPE CON koşulunda PLA'dan anlamlı derecede fark bulundu ancak CHO koşulu ile bir fark bulunamadı.

Sonuç: CHO ağızda çalkalama, PLA ile kıyaslandığında zirve ve ortalama gücü geliştirmez ancak bir nosebo etkisi olarak, CHO ve PLA CON'a göre zirve ve ortalama gücü geliştirir.

Anahtar Kelimeler: Futbol, bisiklet, ağız reseptörleri, ağız çalkalama, ergojenik yardım

\section{Introduction}

The soccer is one of the most popular sports around the world and in elite level, it necessitates highly demanding physical (spriting, jumping, tackling) and mental capabilities especially in match play [1]. Of this physical demands, intermittent sprints are common and also the consist of sprints in short duration ( $<6$ seconds) and punctuated by brief $(<90$ seconds) and inadequate recoveries [2]. The quality and the quantity of sprints especially in the later stage of the soccer game are the contributing factors to win or lose the match in such a way that $0.8 \%$ decrement in sprint speed of player's may have effect on the possibility of losing of the ball, while opponent sprint for the ball at the same time [3]. Therefore, athletes and coaches have been seeking for strategies to improve intermittent sprint performance with incorporating various sprint activities into training plan and implementing acute nutritional interventions before or during training and match [4].

In this respect, carbohydrate $(\mathrm{CHO})$ ingestion before or during exercise particularly in long duration has been shown to increase in endurance (especially in $>1$ hour time trial test protocols) performance due to the effect on the metabolism such as, in specific situtations, sparing liver and muscle glycogen content for later use, maintenance of blood glucose level and raised exogenous $\mathrm{CHO}$ oxidation [5]. It is also important to note that supplementation of CHO sufficiently may help players, while counteracting with metabolic and/or central fatigue during soccer match in which physical and mental performance show a trend to decrease towards to end of each half $[6,7]$. However, feeding of $\mathrm{CHO}$ has been demonstrated to improve exercise performance not only in long duration but also in short duration $(<1$ hour) protocols that metabolic mechanisms do not seem to be responsible for this ergogenic effect [8]. Further, performance benefit seen in such activities are not related to the $\mathrm{CHO}$ oxidation due to the absorption and transportation time of the carbohydrate to the muscle to be used and small rate of exogenous $\mathrm{CHO}$ oxidation, when compared to total $\mathrm{CHO}$ oxidation [9]. To test this phenomenon, also in view of the fact that the buccal mucosa supplies direct pathway to the brain [10], Carter et al. investigated the effect of $\mathrm{CHO}$ mouth rinsing in oral cavity without swallow in endurance trained athletes and showed that rinsing of $\mathrm{CHO}$ solution improved time-trial 
performance via central mechanisms [11]. In support, it has been suggested by mechanistic researches to the presence of $\mathrm{CHO}$ in the oral cavity detected by non sweet taste receptors, in turn, may stimulate brain regions (anterior cingulate cortex, striatum) related to motor activity, reward/motivation which may influence exercise performance especially in endurance-based activities without any changes in blood glucose level $[12,13]$. Similar results were demonstrated by De Pauw et al., in that, rinsing of maltodextrin increased brain activity within the orbitofrontal cortex with no effect on reaction time [14].

Although ingestion of $\mathrm{CHO}$ solution improves endurance performance in prolonged exercise, it is known that feeding with $\mathrm{CHO}$ can cause gastrointestinal distress and lead to decrements in performance especially in some athletes having no tolerance to $\mathrm{CHO}$ ingestion [15]. To eliminate this metabolic handicap, $\mathrm{CHO}$ mouth rinsing without swallowing can be a good strategy. In this manner, mouth rinsing of CHO solution has been reported by most [16-18], but not all studies $[19,20]$ to increase endurance exercise performance. However, since endurance and sprint performances are effected differently from central and peripheral mechanisms, it still remains to be determined whether $\mathrm{CHO}$ mouth rinsing also increases intermittent sprint performance or not. Scarce studies regarding the effects on sprint performance have conflicting results that Beaven et al. reported significant improvements in power output during the first of five sixsecond sprints and others did not [21-25]. The differences in results can be attribute to the training status of participants, dose and the duration of $\mathrm{CHO}$ rinsing protocol, prandial state of participants and the test protocol used [25].

From an evolutionary perspective, under high physiological stress conditions as in the fasted or reduced glycogen state, ergogenic effect of $\mathrm{CHO}$ mouth rinsing may be more apparent. Kasper et al. have reported that $\mathrm{CHO}$ mouth rinsing improved high intensity running capacity following to $45 \mathrm{~min}$. steady-state exercise at $\% 65 \mathrm{VO} 2 \mathrm{max}$ in carbohydrate restricted state [27]. Additionally, it is known that 10 seconds were superior to 5 seconds mouth rinsing duration in time trial performance [15]. It is also important to note that athletes often prefer to perform morning training sessions in fasted state without eating [22]. In this respect, the aim of this study was to examine the effects of $\mathrm{CHO}$ mouth rinsing on intermittent sprint performance in soccer players whose sprint performance can be deteriorated by neural factors especially when sprint decrement score is high [28]. It was hypothesized that $\mathrm{CHO}$ mouth rinsing would improve intermittent sprint performance especially in the later stage of the test protocol.

\section{Material and Method}

Fifteen regional level amateur male soccer players [(mean \pm SD) age: $20.00 \pm 2.44$ years, height: $177.66 \pm 4.80$ m, body mass: $75,02 \pm 6.42 \mathrm{~kg}$ ] voluntarily participated in the study at the end of season. Participants were a part of team at super or regional amateur league for the last 5 years, also engaged in 4-5 training sessions and an official match, regularly in a weekend during the season. The study approved by Ankara University Clinical Research Ethics Committee (no: 12-720-17) and conducted in accordance with the Declaration of Helsinki. All participants were fully informed of the possible risks of the study and the right to refuse to participate in the study before giving written consent.

Owing to the possible placebo effect, participants were informed that the aim of this study was to examine the effect of $\mathrm{CHO}$ mouth rinsing on $\mathrm{BL}$ and $\mathrm{BG}$ before and after intermittet sprint test protocol and so were deceived about the exact aim of the study [23]. The participants attended 4 sessions seperated by 2-4 days within a 12-day period at a testing laboratory in a double-blind, randomized, counterbalanced and crossover research design. The first session was familiarization to

improve the reliability [29] of $12 \times 4$ seconds intermittent sprint testing on a cycle ergometer (Monark Ergomedic 894E, Monark Exercise, AB, Varberg, Sweden) which simulates soccer specific movement pattern [31] and becomes accustomed to 6-20 Borg rating of percevied exertion scale (RPE), also participants' height and body mass were measured. The saddle and handle bars were adjusted to each participant's accordance and remained consistent for each condition. To mimic all procedures in the experimental conditions, water was used as a mouth rinse in the familiarization session. Other 3 sessions were treatments during which participants rinsed a-) $25 \mathrm{ml}$ of $6.4 \%(\mathrm{w} / \mathrm{v})$ tasteless and colourless maltodextrin solution (CHO; Natura, Germany) b-) $25 \mathrm{ml}$ of water (PLA) c-) no rinse as a control (CON). Solutions was rinsed for 10 seconds in the mouth, immediately before each sprint 
and 12 times in total. To make solutions taste matched, both solutions contained same amount of orange flavour. Participants were asked to abstain from caffeine ingestion and vigorous exercise for a minumum of 24 hours before the each condition. To maintain total caloric intake and muscle glycogen level equal between experimental conditions, participants were asked to record their eating patterns with their time and size 24 hours before the familiarization session and repeat this diet before each condition. Participants were reminded to replicate diet and not to do physical activity via mobile phone or e-mail every 4-5 hours within the day prior to 24 hours each experimental conditions. Additionally, verbal confirmation of compliance to these procedures were provided in the morning prior to beginning of the test protocol.

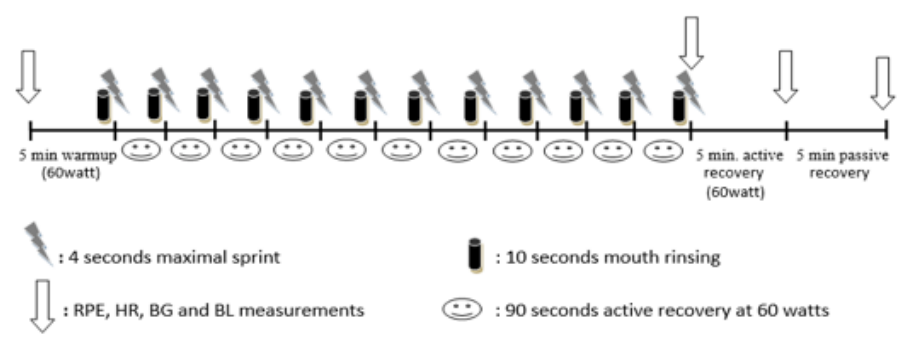

Figure1. Schematic diagram of the $12 \times 4$-s intermittent sprint test procotol.

The schematic representation of the $12 \times 4$-s intermittent sprint test protocol is shown in Figure 1. Experimental conditions began between 8-10 am. in the fasted state after 10 hour night-fasting. Upon arrival the laboratory, prior to intermittent sprint test, in the resting state, (HR) (Polar Team2, Kempele, Finland) was measured followed by $(\mathrm{BL})$ and $(\mathrm{BG})$ concentration were assessed through a $20 \mu \mathrm{L}$ sample obtained from the finger using the valid [31,32] Accutrend Plus anaylser (Roche Diagnostics, Basel, Switzerland). Following $500 \mathrm{ml}$ water intake to prevent dehydration throughout testing, participants began 5 -minutes warm up at 90 Watt $60 \mathrm{rpm}$ on cycle ergometer. In the last 15 seconds of warming up, participants rinsed the solutions 10 seconds in the mouth and expectorating back into a plastic cup. Immediately after rinsing of the solution, participants asked to cycle maximally till the end of 4-seconds sprint and upon reaching $150 \mathrm{rpm}, 0.075 \mathrm{~g} /$ $\mathrm{kg}$ resistance was automatically added to flywheel and 4 seconds sprint began followed by 90 seconds active recovery at 60 watt $60 \mathrm{rpm}$. This pattern was repeated 12 times with 10 seconds mouth rinsing immediately before each 4 seconds sprint. On completion of the intermittent sprint test, the participants cycled at 60 watt $60 \mathrm{rpm}$ to active recovery followed by 5 minutes passive recovery in a seated position. Vigorous verbal encouragement was provided during sprints. Peak and mean power output were calculated with software (Monark Anaerobic Test Version 3.3.0.0). RPE, HR, BG and BL were measured immediately after intermittent sprint test, active and passive recovery periods. All data were analyzed using the IBM SPSS statistics for Windows, version 22.0 (IBM Corp., Armonk, NY, USA). To assess the distribution of all data Shapiro-Wilk test was used. Peak and mean power were analyzed using a $3 \times 12$ (condition $x$ sprint) repeated measures analysis of variance (ANOVA). $\mathrm{RPE}, \mathrm{BG}, \mathrm{BL}$ and $\mathrm{HR}$ datas were anaylzed using $3 \mathrm{x} 4$ (condition $\mathrm{x}$ time) repeated measures ANOVA. Sphericity was anaylzed by Mauchly's test of sphericity followed by the Greenhouse-Geisser adjustment where required. If any differences were identified, Fisher's least significant difference post hoc test was used. The significance leves were set at $p<0.05$. The effect sizes were calculated using partial eta squared $(\eta 2)$ for peak and mean power and were defined as trivial, small, moderate or large [33].

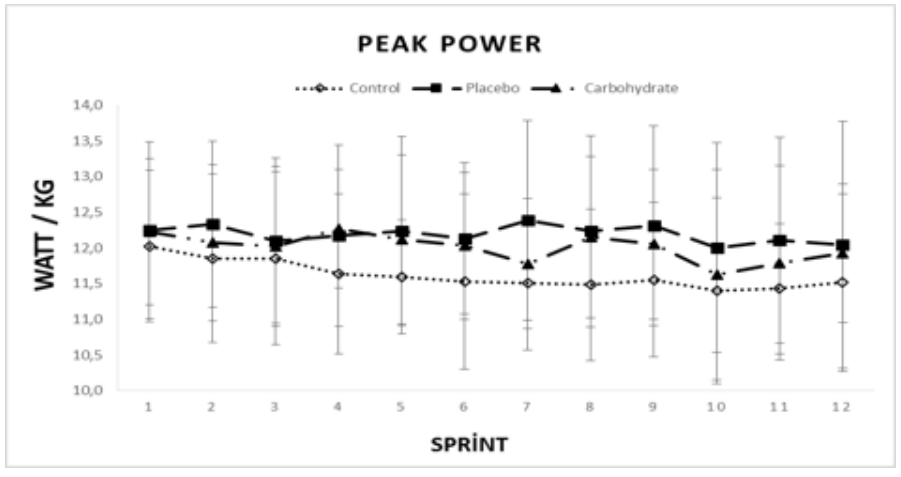

Figure 2. Peak powers for each trial



Figure 3. Mean powers for each trial 


\section{Results}

The peak and mean power outputs are shown in Figure 2 and Figure 3, respectively. There were significant main effects for condition in peak power $(\mathrm{F}=3.533 ; \mathrm{P}=0.043$; $\eta 2=0.20)$ and mean power outputs $(\mathrm{F}=4.491 ; \mathrm{P}=0.020$; $\eta 2=0.24)$. The overall peak and mean power outputs were significantly higher in $\mathrm{CHO}$ and PLA condition compared to $\mathrm{CON}(\mathrm{P}<0.05)$ and there was no significant difference between CHO and PLA ( $>00.05)$ conditions. However, there were no main effects of sprint $(\mathrm{F}=1.248, \mathrm{P}=0.304$, $\eta 2=0.08 ; \mathrm{F}=1.822, \mathrm{P}=0.161, \eta 2=0.11$ ) or condition $\mathrm{x}$ sprint interaction $(\mathrm{F}=0.771, \mathrm{P}=0.761, \eta 2=0.05 ; \mathrm{F}=0.950$, $\mathrm{P}=0.529, \eta 2=0.06$ ) in peak and mean power, respectively. There were no main effect of condition $(\mathrm{F}=0.205, \mathrm{P}=0.816$, $\eta 2=0.01 ; \mathrm{F}=0.327, \mathrm{P}=0.724, \eta 2=0.02)$ in peak and mean power, respectively.

$\mathrm{BL}, \mathrm{BG}, \mathrm{HR}$ and RPE variables are shown in figure 4, 5, 6, 7 respectively. There were no main effects of condition $(\mathrm{F}=2.947, \mathrm{P}=0.069 ; \mathrm{F}=1.676, \mathrm{P}=0.205)$ and condition $\mathrm{x}$ time interaction $(\mathrm{F}=1.621, \mathrm{P}=0.151 ; \mathrm{F}=2.323, \mathrm{P}=0.085)$ in $\mathrm{BL}$ and $\mathrm{BG}$ variables, respectively. However, as expected, $\mathrm{BL}$ and $\mathrm{BG}$ significantly increased with time through the end of test protocol $(\mathrm{F}=108.276, \mathrm{P}=0.001$; $\mathrm{F}=22.809, \mathrm{P}=0.001$ ) respectively. As for $\mathrm{HR}$, there were main effects of condition $(\mathrm{F}=5.172, \mathrm{P}=0.012)$ and time ( $\mathrm{F}=622.348, \mathrm{P}=0.001)$. Overall $\mathrm{HR}$ was significantly higher in $\mathrm{CON}$ compared to $\mathrm{CHO}$ and PLA $(\mathrm{P}<0.05)$, but there was no difference between $\mathrm{CHO}$ and PLA condition $(\mathrm{P}>0.05)$. In addition, HR significantly increased with time $(\mathrm{P}<0.05)$ and there were no main effects of condition $\mathrm{x}$ time interaction $(\mathrm{F}=0.533, \mathrm{P}=0.782)$. Lastly, there were significant main effects for condition $(\mathrm{F}=3.769, \mathrm{P}=0.036)$ and time $(\mathrm{F}=442.875, \mathrm{P}=0.001)$ for $\mathrm{RPE}$. $\mathrm{CON}$ condition had significantly higher RPE values than PLA, but there was no difference between $\mathrm{CON}$ and $\mathrm{CHO}$, also between $\mathrm{CHO}$ and PLA condition ( $\mathrm{P}>0.05)$. RPE significantly increased with time as expected $(\mathrm{P}<0.05)$. Additionally, there was no significant main effect of condition $\mathrm{x}$ time interaction $(\mathrm{F}=1.729, \mathrm{P}=0.156)$.

\section{Discussion}

The aim of the current research was to investigate the effects of $\mathrm{CHO}$ mouth rinsing on intermittent sprint performance in soccer players. Contrary to our hypothesis, main findings from this study suggest that CHO and PLA mouth rinse significantly improved intermittent sprint performance in comparison to $\mathrm{CON}$ trial and there were no performance differences between $\mathrm{CHO}$ and PLA conditions. Since $\mathrm{CHO}$ increased sympathetic activation and plasma catecholamine leves [34], HR values during the test protocol was expected to be higher in $\mathrm{CHO}$ condition, however, inexplicably, HR was significantly higher in CON trial compared to CHO and PLA in spite of the higher peak and mean power outputs. Also, $\mathrm{CHO}$ mouth rinsing had no effect on RPE, BL and BG variables during the sprint test and recovery periods.

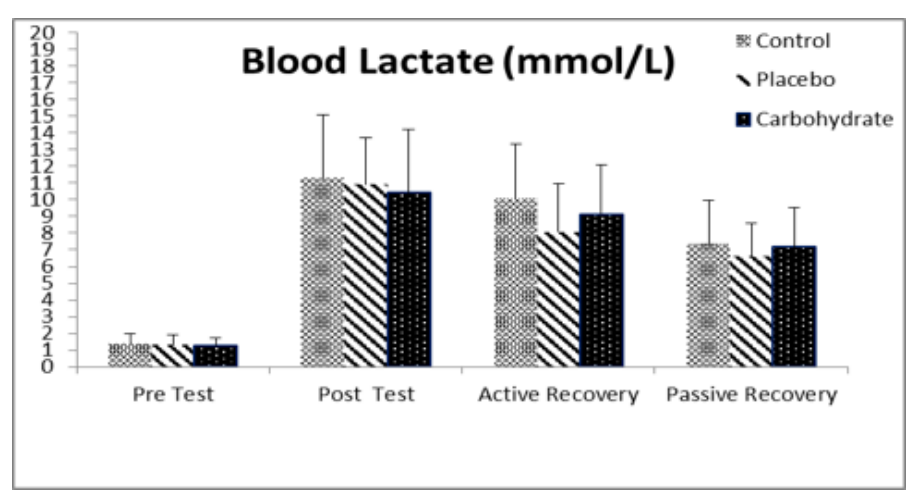

Figure 4. Blood lactate for each trial

Ergogenic mechanisms of $\mathrm{CHO}$ mouth rinsing are believed to relate to the stimulation of the cerebral cortex that increase sensorimotor cortex activation resulting in increased motor output and enhanced performance [35]. Furthermore, orally rinsing of $\mathrm{CHO}$ has been shown to attenuate decrease in the motor activity and increase corticomotor excitability especially in the fatigued muscle to a greater extend than fresh muscle [12]. In this study, aforementioned improvement in power output was not confirmed between PLA and CHO condition and this may be due to the longer recovery periods between sprints that allow participants to recover sufficiently. Futher, having no difference in power output between the first and the last sprint in the test protocol supports the idea. Due to the fact that supposed ergogenic effect of $\mathrm{CHO}$ rinsing would occur via central mechanisms and greater in fatigued state, future research should investigate whether recovery duration between sprints that have large effect on neuromuscular performance would be the determinant factor in multiple sprint protocols. Dorling et al. suggested that rinsing of $\mathrm{CHO}$ does not improve intermittent sprint performance during field-based test protocol simulating soccer movement patterns [22]. In another field-based 
test with a shorter recovery time between sprints, $\% 6$ maltodextrin solution did not increase repeated sprint performance in under-15 soccer players [25]. Contrary to our argument, the authors in this two study proposed that the maximum characteristic of the test protocols may induce other factors causing to reduction in phospate and phosphocreatine stores, in turn, may negate the ergogenic effect of $\mathrm{CHO}$ mouth rinsing. But, metabolic reasons can not be the case for our test protocol consisting of long recovery periods between sprints and relatively short test duration in total (approximately 17.5 minutes) which do not to drive participants to be in a peripheral fatigue state [2]. Additionally, our result is consistent with the previous research that reported no benefit of $\mathrm{CHO}$ rinsing on sprint activities during early morning soccer scrimmaging in female soccer players [23]. However, it is important to note that 72-m shuttle run performance in the first bout approached statistical significance in $\mathrm{CHO}$ condition. Commonly, the observations that have suggested the beneficial effects of $\mathrm{CHO}$ mouth rinsing on sprint power output have mostly reported improvement in the first or early stages of the sprints. In contrast to our result, in the Beaven's study, 5 seconds glucose rinsing has been demonstrated to improve peak power output in the first of five 6 seconds sprints via possibly supraspinal mechanisms that increase neural drive to the motor units [21]. The discrepancies between our results and Beaven's can be related to the carbohydrate type (maltodextrin vs. glucose) rinsed before the sprints. Maltodextrin may exerts its effect in the brain tissue supposedly different from glucose [13]. This argument supported recently that glucose ingestion and mouth rinse has been shown to increase peak power output compared to artificial sweetener aspartame but not maltodextrin.

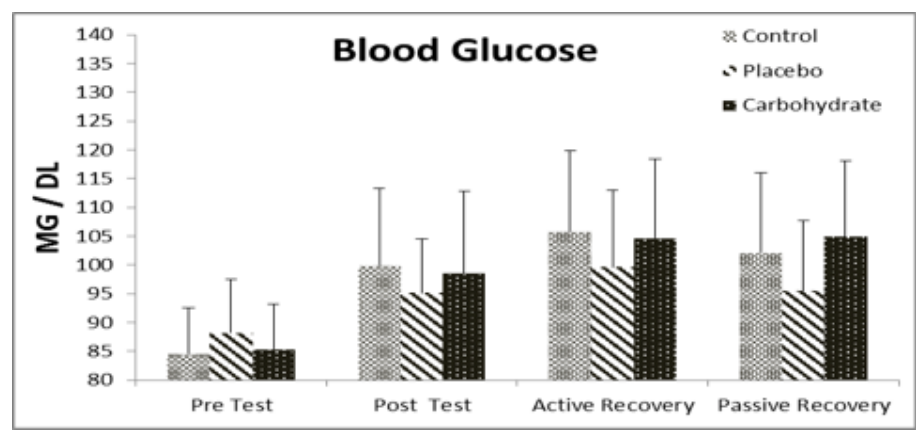

Figure 5. Blood glucose for each trial
True aim of the current study was not told to participants and it may have some impact on the results [24]. Chong et al. found that 5 seconds mouth rinse with a maltodextrin or glucose compared to water and no rinse condition did not improve 30-s maximal sprint performance in trained male cyclists. Further, the author speculated that the artificial sweetener used in the study may mask potential effect of a CHO rinsing. However, it is known that the presence of sweeteners in the oral cavity can not activate brain regions that are responsive to glucose and maltodextrin such a way that dependent on caloric content not on sweetness [13]. The similar research design was used by Muhammed et al. and they reported that compared to no-rinse condition, $\mathrm{CHO}$ and PLA increase $10 \mathrm{~km}$ time trial performance in ramadan fasting during heat stress [36]. Furthermore, improvement in the performance with the mouth rinse compared to no-rinse condition was shown by another study [37]. At the present, this is just speculation but detection of "nocebo" effect in the mouth rinse literature may be related to the deception of participants about the aims of the study which might drive them involuntarily to concentrate just on rinse conditions.

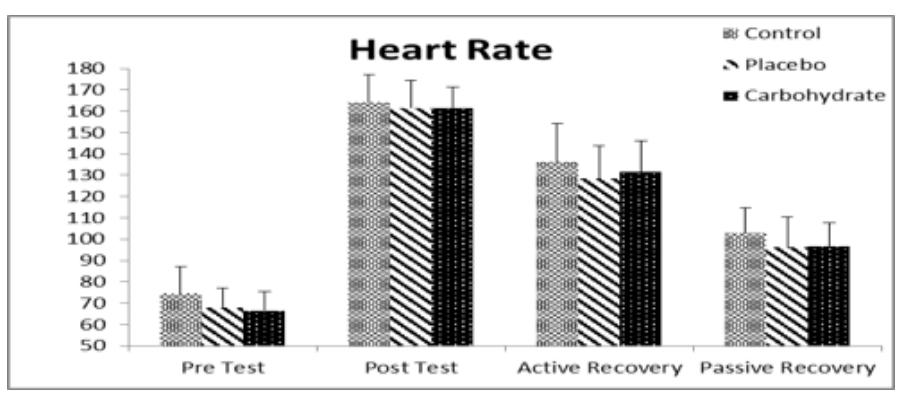

\section{Conclusion}

In summary; carbohydrate mouth rinsing dose not significantly improve intermitent sprint performance and recovery paramaters in soccer players. Further confirmatory study is required to investigate the effects of $\mathrm{CHO}$ mouth rinse in a protocol that has shorter recovery time between sprints.

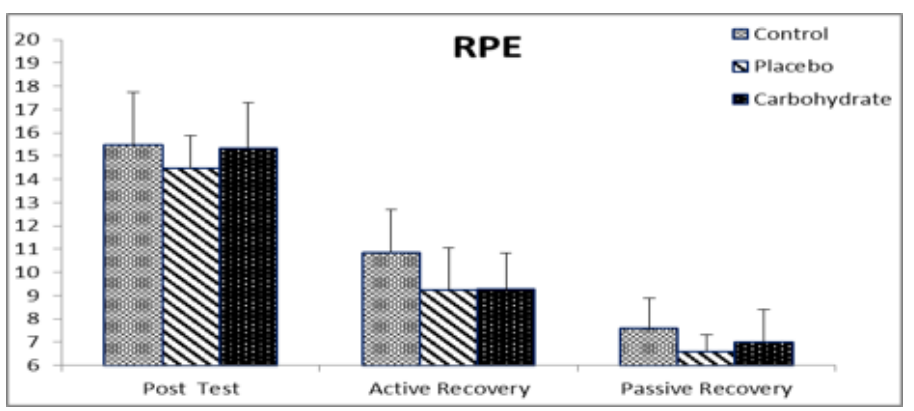

Figure 7. Rpe values for each trial 


\section{Declaration of conflicting interests}

The author declared no conflicts of interest with respect to the authorship and/or publication of this article.

\section{References}

1. Stolen T, Chamari K, Castagna C, Wisloff U. Physiology of soccer: an update. Sports Med 2005;35:709-16.

2. Girard O, Mendez-Villanueva A, Bishop D. Repeated-sprint ability - part I factors contributing tofatigue. Sports Med 2011;41:673-94.

3. Paton CD, Hopkins WG, Vollebregt L. Little effect of caffeine ingestion on repeated sprints in team-sport athletes. Med Sci Sports Exerc 2001;33:822-5.

4. Russell M, Kingsley M. The efficacy of acute nutritional interventions on soccer skill performance. Sports Med 2014;41:957-70.

5. Coyle EF, Coggan AR, Hemmert MK, Ivy JL. Muscle glycogen utilization duringprolongedstrenuous exercise when fed carbohydrate. J Appl Physiol 1986;61:165-72.

6. Oliveira CC, Ferreira D, Caetano C, et al. Nutrition and supplementation in soccer. Sports 2017;5:28.

7. Bangsbo J. Physiological demands of football. Sports Sci Exch 2014;27:1-6.

8. Carter JM, Jeukendrup AE, Mann CH, Jones DA. The effect of glucose infusion on glucose kineticsduring a 1-h time trial. Med Sci Sports Exerc 2004;36:1543-50.

9. Jeukendrup AE. Carbohydrate intake during exercise and performance. Nutrition 2004;20:669-77.

10. Nicolazzo JA, Reed BL, Finnin BC. The effect of various in vitro conditions on the permeabilitycharacteristics of the buccal mucosa. J Pharmaceu Sci 2003;93:2399-410.

11. Carter JM, Asker AE, Jones DA. The effect of carbohydrate mouth rinse on 1-h cycle time trial performance. Med Sci Sports and Exerc 2004;36:2107-11.

12. Gant N, Stinear C, Byblow W. Carbohydrate in the mouth immediately faciliates motor output. Brain Research 2010;2:151-8.

13. Chambers ES, Bridge MW, Jones DA. Carbohydrate sensing in the human mouth, effects on exerciseperformance and brain activity. J Physiol 2009;15:1779-94.
14. De Pauw K, Roelends B, Knapean K, Polfliet M, Stiens J, Meeusen R. Effects of caffeine andmaltodextrin mouth rinsing on P300, brain imaging and cognitive performance. J Appl Physiol 2015;118:776-82.

15. Van Nieuwenhoven MA, Brouns F, Kovacs EMR. The effect of two sports drinks and water on GI complaints and performance during an 18-km run. Int J Sports Med 2005;26:281-5.

16. Sinclair J, Bottoms L, Flynn C, et al. The effect of differentdurations of carbohydrate mouth rinse on cycling performance. Eur J Sport Sci 2014;14:259-64.

17. James RM, Sarah R, Rollo I, James LJ. No dose response effect of carbohydrate mouth rinse on cycling time-trial performance. Int $\mathrm{J}$ Sport Nutr Exerc Metabol 2017;26:25-31.

18. Rollo I, Cole M, Miller R, Williams C. Influence of mouth rinsing a carbohydrate solution on 1-h running performance. Med Sci Sports Exerc 2010;42:798-804.

19. Kulaksız TN, Koşar ŞN, Bulut S, et al. Mouth rinsing with maltodextrin solutions fails to improve time trial endurance cycling performance in recreational athletes. Nutrients 2010;8:269-83.

20. Beelen M, Beghuis J, Bonaparte B, Ballak SB, Jeukendrup AE, Van Loon LJC. Carbohydrate mouth rinsing in the fed state: lack of enhancement of time-trial performance, Int Journal Sport Nutr Exerc Metabol 2009;19:400-9.

21. Beaven CM, Maulder P, Pooley A, Kilduff L, Cook C. Effects of caffeine and carbohydrate mouthrinses on repeated sprint performance. Appl Physiol Nutr Metabol 2013;38:633-7.

22. Dorling JL, Earnest CP. Effect of carbohydrate mouth rinsing on multiple sprint performance. J Int Soc Sports Nutr 2013;10:41.

23. Pribyslavska V, Scudamore EM, Johnson SL, et al. Influence of carbohydrate mouth rinsing on running and jumping performance during early morning soccer scrimmaging. Eur J Sport Sci 2016;16:441-7.

24. Chong E, Guelfi KJ, Fournier PA. Effect of a carbohydrate mouth rinse on maximal sprintperformance in competitive male cyclist. J Sport Sci Med Sport 2011;14:162-7.

25. Bortolotti H, Pereira LA, Oliveira RS, Cyrino ES, Altimari LR. Carbohydrate mouth rinse does notimprove repeated sprint performance. Brazil J Kinanthropomet Human Perform 2013;15:639-45. 
26. Peart DJ. Quantifying the effect of carbohydrate mouth rinsing on exercise performance. J Strength Conditioning Research 2017;31:1737-43.

27. Kasper AM, Cocking S, Cockayne M, et al. Carbohydrate mouthrinse and caffeine improves high-intensity interval running capacity when carbohydrate restricted. Eur J Sport Sci $2016 ; 16: 560-8$

28. Racinais S, Bishop D, Denis R, Lattier G, Mendez-Villaneuva A, Perrey S. Muscle deoxygenationand neural drive to the muscle during repeated sprint cycling. Medicine Sci Sport Exercise 2007;39:268-74

29. Hopkins WG, Schabort EJ, Hawley JA. Reliability of power in physical performance tests. Sports Med 2001;31:211-34.

30. Mayhew SR, Wenger HA. Time-motion analysis of Professional soccer. J Hum Mov Stud 1985;11:49-52.

31. Fell JW, Rayfield JM, Gulbin JP, Gaffney PT. Evaluation of the accusport lactate analyser. Int J Sports Med 1998;19:199-204.

32. Coqueiro Rda S, Santos MC, Neto Jde S, Queiroz BM, Brügger NA, Barbosa AR. Validity of a portable glucose, total cholesterol and triglycerides multi-analyzer in adults. Bio Res Nurs $2014 ; 16: 288-94$

33. Cohen J. A power primer. Psychol. Bull 1992;112:155-9.

34. 3Welle S, Lilavivathana U, Campbell RG. Increased plasma norepinephrine concentrations andmetabolic rates following glucose ingestion in man. Metabolism: Clinical and Experimental 1980;29:806-9.
35. Turner CE, Byblow WD, Stinear CM, Gant N. Carbohydrate in the mouth enhances activation ofbrain circuitry involved in motor performance and sensory perception. Appetite 2014;80:212-9.

36. Muhamed AMC, Mohamed NG, Ismail N, Aziz AR, Singh R. Mouth rinsing improves cycling endurance performance during Ramadan fasting in a hot humid enviroment. Applied Physiol, Nutr Metabol 2013;39:458-64.

37. Clarke ND, Hammond S, Kornilios E, Mundy PD. Carbohydrate mouth rinse improves morning high-intensity exercise performance. Eur J Sport Sci 2017;17:955-63.

38. Coyle EF, Coggan AR, Hemmert MK, Ivy JL. Muscle glycogen utilization during prolonged strenuous exercise when fed carbohydrate. J Appl Physiol 1986;61:165-72.

Corresponding Author: Raci Karayigit, Department of Coaching Education, Faculty ofSports Sciences, Ankara University, 06830 Ankara, Turkey

E-mail: racikarayigit@hotmail.com 